\title{
THE CODES OF BELT AND ROAD INITIATIVE: A MEDIA CONTENT ANALYSIS
}

\author{
KUŞAK VE YOL İNISIYYATIIFINIIN KODLARI: BİR MEDYA İÇERİK ANALİİ
}

\author{
Büșra GEZİKOL ${ }^{1}$ - Tuğba ONUR ${ }^{2}$ - Hakan TUNAHAN ${ }^{3}$
}

\begin{abstract}
The aim of this study is to examine the reflections of China's One Belt One Road Project in US press from the date when the project was announced to 2019 through content analysis technique. For this purpose, the news in The New York Times which is the oldest and leading newspaper in the field of economy in USA and has audiences who have liberal and at the left of the center political values, has been analyzed. Some of the codes and categories extracted have become prominent for all those years. These are; Maritime Silk Road, Pakistan, China and Kazakhstan codes under OBOR Member Countries category; Facilities Connectivity, Financial Integration, Policy Coordination and Industrial Cooperation codes under OBOR Project Priorities category and Italy and America codes under Other Countries category.
\end{abstract}

Keywords: One Belt One Road, Media Content Analysis, Financial Integration, Industrial Cooperation, Facilities Connectivity, The New York Times

\section{Öz}

Bu çalışmanın amacı, Çin'in Tek Kuşak Tek Yol Projesi'nin projesini, duyurulduğu tarihten 2019 yılına kadar içerik analizi tekniği ile yansımalarını incelemektir. Bu amaç doğrultusunda ABD'de ekonomi alanında en eski ve önde gelen bununla birlikte liberal ve merkez siyasi değerlerin solunda okuyucuları bulunan The New York Times'daki haberler analiz edilmiştir. Tüm yılları kapsayan analizde bazı kategori ve kodların ön plana çıktığı görülmektedir. Bunlar: Deniz İpek Yolu, OBOR Üye Ülkeler kategorisi altında Pakistan, Çin ve Kazakistan kodları, OBOR Proje Öncelikleri kategorisi altında Altyapı Entegrasyonu, Finansal Entegrasyon, Politik İlişkiler ve Sektörel İşbirliği kodları ve Diğer Ülkeler kategorisi altındaki İtalya ve Amerika kodlarıdır.

Anahtar Kelimeler: Tek Kuşak Tek Yol, Medya İçerik Analizi, Finansal Entegrasyon, Sektörel İşbirliği, Altyapı Entegrasyonu, The New York Times

\footnotetext{
${ }^{1}$ Arş.Gör., Sakarya Üniversitesi, bgezikol@ @akarya.edu.tr, Orcid: 0000-0002-3131-0162

${ }^{2}$ Dr, İstanbul Üniversitesi, tuggbaaonur@gmail.com, Orcid: 0000-0002-1459-8205

${ }^{3}$ Doç.Dr., Sakarya Üniversitesi, İşletme Fakültesi, Uluslararası Ticaret Bölümü, htunahan@ sakarya.edu.tr, Orcid: 0000-0002-9556-214X
}

Makale Türü: Araştırma Makalesi - Geliş Tarih:16/01/2020 - Kabul Tarihi:27/03/2020

DOI:10.17755/esosder.675958

Atıf için: Elektronik Sosyal Bilimler Dergisi, 2020; 19(75):1507-1516 


\section{Introduction}

One Belt One Road, named as Belt and Road Initiative in 2017, (OBOR) is an international economic cooperation project announced by Chinese President Xi Jinping in November 2013. In addition to revitalization of the Old Silk Road, the project has the vision of creating new economic, maritime, energy and digital corridors. OBOR supports a number of important infrastructure projects, including cross-border high-speed railways, freight railways, oil / gas pipeline connections, telecommunications and electrical connection arrangements. In total, this project reflects a much more comprehensive structure than a simple infrastructure development (Huang, 2016). Having a dynamic structure and covering nearly 70 countries clearly shows the scale and global structure of the project. The main objective of OBOR is to promote partnership and security cooperation by establishing economic and social ties among countries (Kwang et al., 2018). In order to realize this cooperation and partnership, five main priorities which figured in Belt and Road Portal has been specified. These are "Policy Coordination", "Facilities Connectivity", "Unimpeded Trade", "Financial Integration" and "People-to-people Bond" (Belt and Road Official Portal, 2019). In April 2019, "Industrial Cooperation" was added as the sixth priority (Belt and Road Official Portal, 2019). When the reports and documents related to these priorities are examined; priority of Policy Coordination aims to ensure stability in infrastructure activities in the countries included in OBOR, to establish good legal and political relations and to make agreements for infrastructure projects. Facilities Connectivity includes economic corridors and activities to achieve an integrated and composite structure in terms of road, rail, maritime, airline, pipeline and information networks for OBOR's members. Unimpeded Trade, as another priority, emphasizes taking facilitating approach to trade and investment and thus triggering economic growth. Applying new investment and financing models, enabling commercial banks and financial institutions to produce joint solutions are considered as Financial Integration. People-to-people Bond is considered as the recognition of cultures, diversity and the spread of services such as tourism, education, health among the participating countries. Industrial Cooperation refers to the investments which is made by created participating countries to create industry, supply, service and value chains.

China has two main economic motivations in realizing the OBOR project. The first is China's search for profitable investment areas to absorb surplus production in sectors such as iron-steel and cement. The second main motivation of China is its desire to reach Europe, Middle East and Africa more easily by the route it will create. Since the possibility of interruption or restriction of China's access to maritime trade, which owes its prosperity to trade with the world, poses a serious security risk. Thus, the opportunity for China to maintain its contacts with Europe, the Middle East and Africa on alternative routes could ease the cost of such a crisis (Okur, 2017). In essence, China's project has a geopolitical character as well as economic. In this respect, the concept that best describes "One Belt One Road" is geoeconomics (Blackwill and Harris, 2016).

China has signed investment agreements to implement OBOR with countries or regions which have geopolitical importance. In addition, after the project was accepted as an official government strategy, infrastructure and economy development activities have started in fourteen provinces of China, mainly Shaanxi, Gansu, Qinghai, Ningxia, Xinjiang, Sichuan, Chongqin, Yunnan and Guanxi.

China has also asked, in high-level visits, South Korea, Mongolia, India, Europe and Russia to support of the Belt- Road Project (Durdular, 2016). 


\section{Literature Review}

In the literature, there are studies which analyze the OBOR from different approaches. This study focuses on media content analysis about OBOR because of that many news about OBOR especially in China, are published in the press of countries which contribute to the project, or have prejudices against the project. So the literature and the analysis below is shaped in this context

The foundations of news text analysis in the literature dates back to Lasswell's study of political propaganda published in 1927. The aim of Lasswell's work is to interpret the propagandas based on the discourses and words of the politicians and to determine the prominent points. Media content analysis actually employs this structure and method.

In literature, media content analysis studies on OBOR are especially observed in recent years. In their study, Xiao et al. (2019) have examined how the project took place both in the Chinese media (China Daily) and US media (The New York Times) which evaluate China as a rival country. In this study, it is seen that the Chinese media has focused on the concrete details of the project while the US media has emphasized the political sides of the project. Although Chinese media has reported positive news, US media has a negative attitude. Zhang and Wu's (2017) studies are similar to Xiao's. China Daily is also used in this study, but the Financial Times is chosen as the comparative newspaper. Chinese media has emphasized the very peaceful nature of the project and the development of international cooperation while Financial Times has emphasized that China is an authoritarian and geopolitical threat. $\mathrm{Hu}$ (2019) has another study similar to the above studies. The study which discusses Daily China in China and CNN and CNBC in the USA news, shows that the OBOR project has not found enough ground in the West. As a result of qualitative analysis, it is mentioned that China had problems with communication, detailing and reporting of the project. Xin and Matheson (2018) have investigated the metaphors OBOR project in Englishlanguage media. News published in the UK, India, Pakistan, Australia, USA and Africa have examined. It has found that UK, India, Australia and USA have emphasized the project with metaphors such as war, slogan, campaign, game and strategy while Pakistan and Africa have emphasized renewal, golden luck and historical cooperation metaphors. Hatef and Luqiu (2018) have focused on Afghanistan which is one of the most important countries in OBOR initiative. As a result of analysis of the news published in China's People Daily and Global Times; the project will be beneficial for both China and Afghanistan which is in political turmoil. In their work on Pakistan and India which are two important countries to be affected by China's project; Huang (2018) have determined Pakistan's positive attitudes to the project and India's negative attitudes. According to authors, India have thought China is a threat while Pakistan has a positive but skeptical approach. Afzaal et al. (2019) have indicated that Pakistan has a positive approach to the project. In the study, the content of China-Pakistan Economic Corridor in Pakistan and Chinese press has been analyzed and it is seen that the Pakistan press have friendly and positive discourses about China. In his study, Ravitsky (2018) has examined the reflections of the project in Russia's media which is considered as an important country in China's project. The news has emphasized that Russia and China are two countries that will benefit from the strategic partnership and the project.

Arifon et al. (2019) who has examined the approaches of European countries to the project, have investigated the content of projects from the European perspective by examining Le Monde (France), The Guardian (United Kingdom), Sueddeutsche Zeitung (Germany), and El País (Spain) and also from Chinese side by analyzing Global Times, Xinhua News and People's Daily. While expressions such as cooperation and win-win become prominent on the Chinese side, European media doesn't take any notice of this project and it expresses that this project is a one-man dance show. 
Herrero and Xu (2019)'s study has examined OBOR in general terms and image of project in all countries. This study has covered 2017-2018 period and used Global Database of Events, Language, and Tone (GDELT) data set which is published in 100 languages and 132 countries. It is seen that the content published about OBOR is mostly emphasized on trade and investments and also the project has positive replications.

As a result, there are some countries that think China's project will be beneficial and will create opportunities for economic development and growth, although there are also countries that see China as a political risk.

\section{Purpose, Scope and Limitations of the Study}

In US Secretary of State Hillary Clinton's statement in July 2011, she mentioned a plan called the "New Silk Road Initiative". This statement has been emphasized that US have encouraged private sector investment in transport and energy infrastructure in Afghanistan (The New York Times, 2013). Two years after this statement, China's President Xi Jinping brought up the OBOR project as part of the revival of the "Old Silk Road". Therefore, we evaluate that USA and China are the leading countries in the emergence of this project.

The aim of this study is to examine the reflections of China's global project in US press. It is considered that US is a main competitor of China therefore it is meaningful to examine the news which is published in US. From the perspective of the US, this study evaluates how the countries involved or not in the project are included in the news content, which aspects of the project are more emphasized and which topics related to integration come to the forefront. Since Jinping first mentioned the project in 2013, the time period in the study was determined as 2013-2019 (21.08.2019).

Between 2013-2019, 195 news articles have been received from the NY Times newspaper web site about OBOR. However, some of these news was eliminated due to the fact that they consist of only videos and images and didn't provide detailed information about the project. So, 75 news published in The New York Times which is oldest and leading newspaper in the field of economy in USA and has audiences who have liberal and at the left of the center political values, are analyzed. NY Times newspaper was chosen because of its power, popularity and liberal character (Pew Research Center, 2014).

Table 1: Total Number of News by Year Year Number of The News

\begin{tabular}{|l|l|}
\hline 2013 & 3 \\
\hline 2014 & 3 \\
\hline 2015 & 7 \\
\hline 2016 & 5 \\
\hline 2017 & 29 \\
\hline 2018 & 17 \\
\hline 2019 & $11^{*}$ \\
\hline TOTAL & $\mathbf{7 5}$ \\
\hline
\end{tabular}

$*$ as of 21.08.2019 
"OBOR", "One Belt One Road", "Belt Road Initiative", "New Silk Road" and "New Silk Road Initiative" keywords are used for searching in NY Times web site. When Table 1 is examined, it is seen that OBOR is more involved in this media after 2017.

\section{Analysis Process of the Study}

75 news have examined through one of the qualitative research methods, document (content) analysis technique. News have been examined and compared as document therefore categories and codes have been extracted. Coding is the first step of analysis in qualitative research and forms the basis for the latter (Punch, 2016: 193). The coding process gathers text and visual data into smaller categories (Creswell, 2018: 184).

Nine different categories are created based on the 75 news content and the report published on the official portal of the OBOR project on April 22, 2019. These categories are classified as "Maritime Silk Road", "Digital (Information) Silk Road", "Economic Corridors", “Energy Corridor”, “Renewable Energy Corridor”, “OBOR Project Priorities”, “OBOR's Global Effects", “OBOR Member Countries" and "Other Countries". It is seen that some categories and codes come to the forefront when all the years are taken into consideration in the context of media content analysis.

The news in the Maritime Silk Road category includes content about port investments in African countries and Europe. In addition, the creation of alternative routes and the realization of financial and infrastructure investments are mentioned in the contents.

The Digital Silk Road category is especially found in the news of 2019. This category actually states that China also deals with the project in a different direction than the logistics and infrastructure project: It is the technological investments

The prominent Economic Corridors are listed in Table 2. As it is seen, Pakistan and the Central-West Asia Corridor are highlighted corridors on news content.

Table 2: Highlights in the Economic Corridor Category

Economic Corridor

\section{Document}

\begin{tabular}{|c|l}
\hline China-Central and West Asia Economic Corridor & 14 \\
\hline China-Pakistan Economic Corridor Economic & 9 \\
\hline $\begin{array}{c}\text { Bangladesh-China-India-Myanmar } \\
\text { Corridor }\end{array}$ & 8 \\
\hline New Eurasia Land Bridge Economic Corridor & 4 \\
\hline China-Mongolia-Russia Economic Corridor & 0 \\
\hline Sino-Indochina Peninsula Economic Corridor & 0 \\
\hline
\end{tabular}

In the Energy Corridor category, there are news about Central Asian Natural Gas and Oil Pipeline. In addition, some of the news content emphasizes the Renewable Energy Corridor.

Table 3 shows which project priorities is more remarkable than others. It is seen, Facilities Connectivity and Financial Integration are more remarkable priorities. 
Table 3: Highlights in Project Priorities Category

Project Priorities

Document

\begin{tabular}{|l|l|}
\hline Facilities Connectivity & 41 \\
\hline Financial Integration & 37 \\
\hline Policy Coordination & 30 \\
\hline Industrial Cooperation & 22 \\
\hline Unimpeded Trade & 15 \\
\hline People-to-people Bond & 5 \\
\hline
\end{tabular}

In OBOR's Global Effect category, it is mentioned that the project will create serious transformations in countries in terms of trade and economy. In the category of OBOR Member Countries, East Asian countries stand out as region while Kazakhstan and Pakistan are frequently mentioned as individual countries.

In the Other Countries category, non-OBOR member countries are considered. In Table 4, it is seen that European countries are among the prominent countries.

\section{Table 4: Highlights in Other Countries Category}

Other Countries

\begin{tabular}{|l|l|}
\hline US & 31 \\
\hline Germany & 9 \\
\hline Italy & 9 \\
\hline Greece & 9 \\
\hline France & 6 \\
\hline
\end{tabular}

Figure 1 shows in general terms the categories-codes and their relations in all the news for the 2013-2019 years. It is seen that Some of the codes and categories extracted have become prominent for all those years.

These categories are: Maritime Silk Road; Pakistan, China and Kazakhstan codes under OBOR Member Countries category; Facilities Connectivity, Financial Integration, Policy Coordination and Industrial Cooperation codes under OBOR Project Priorities category and Italy and America codes under Other Countries category. It is also seen that there is a relationship between Maritime Silk Road category and China and Italy codes. It is also found that Pakistan code is associated with Financial Integration and Facilities Connectivity codes. The Italian code is associated with the Policy Coordination and Industrial Cooperation codes. It is seen that Kazakhstan code is also related to Industrial Cooperation code. 


\section{Figure 1: Category-Code Relations for All Years}

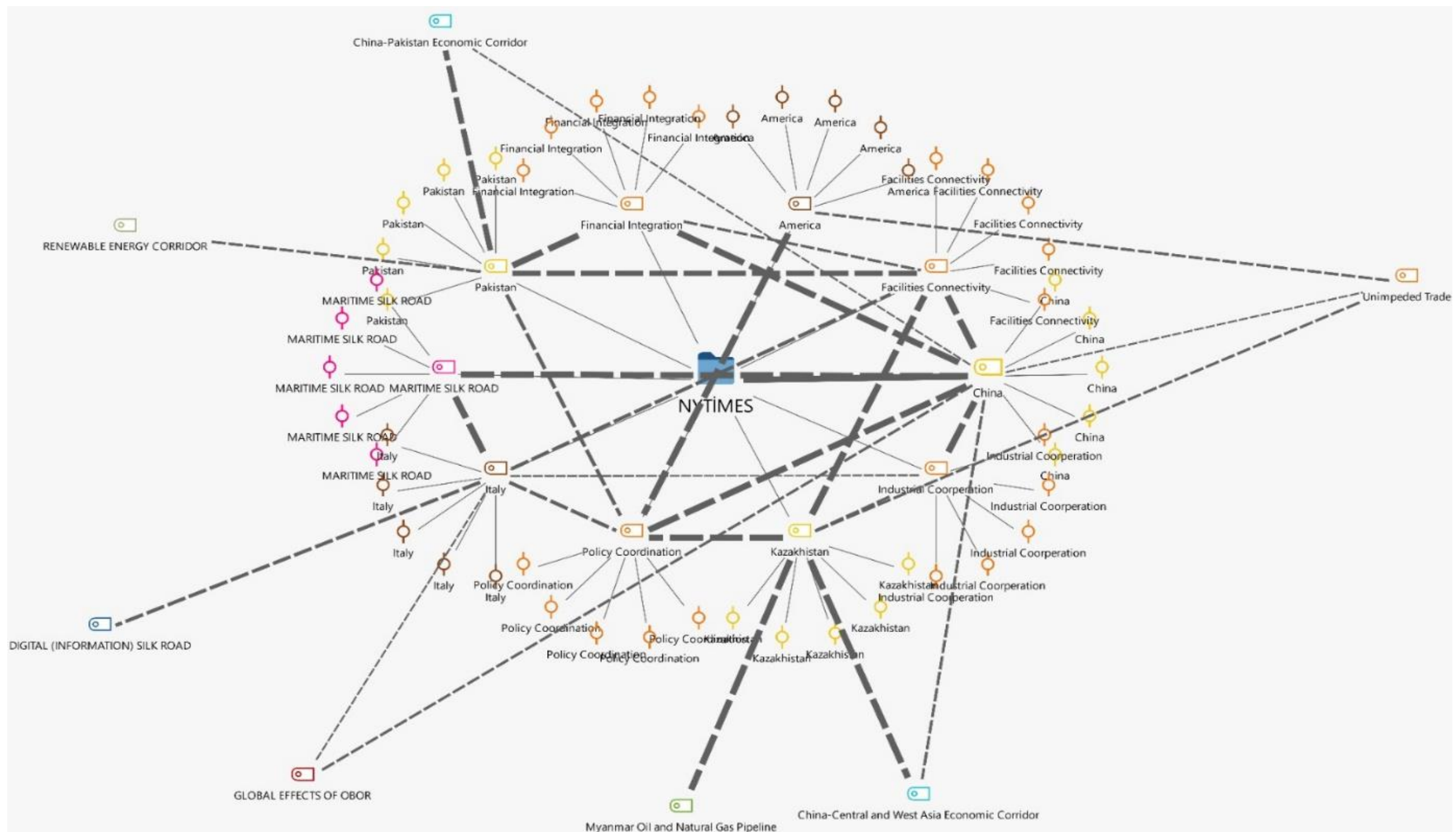




\section{Conclusion}

In 1978, under the leadership of Deng Xiaoping, who converted the country to a market economy and created a socialism of its own character, China has become one of the countries that benefit the most from globalization. OBOR project which headed by Xi Jinping as a new wave of China, has been criticized being a Marshall Plan or having a neo-colonialist approach from the West. There are also opinions that China's approach to this project can be explained by the term Confucianist Tianxia, which includes the idea that the world is a single family.

Unlike the other studies, this study aims to determine the key priorities, strategic regions and evolving direction of the project, the perspective of competitor countries by the way of content analysis.

As a matter of fact, the project is progressing with the leadership of China and the participation of many countries. China recognizes that progress of the project will be difficult if the countries involved in OBOR don't have a moderate approach. Therefore, China provides both infrastructure and financial support to countries. According to the news published on the official portal of the project on 20.12.2019; China invested $\$ 12.78$ billion in 56 OBOR member countries in 11 months (Belt and Road Official Portal, 2019). Indeed, in our study it is seen that infrastructure and financial integration codes has become prominent. In addition to these, China has realized sectoral investments in many countries for the project priorities.

Especially in the analysis of media content, it is seen that Kazakhstan, Pakistan and Italy are prominent because of their strategic position and their importance in the long-term plans of the project. Maritime Silk Road and Industrial Cooperation codes in our study confirms China's desire in port investments (The New York Times, 2019) and maritime breakthroughs (E-Commerce Blog, 2019) in Italy, which are supposed to be the base of opening up to Europe. In addition, it is seen that Policy Coordination with Italy has emerged in the analysis. Although Germany and France don't have an interest in China's project, Italy has warm relationship with China because the project's economic, political and sectoral contribution.

Facilities Connectivity and Financial Integration codes are prominent and related to Pakistan. In fact, China-Pakistan relations have been progressing in the pre-OBOR project. The issue of the economic corridor in 2013 aimed to connect China with Gwadar port of Pakistan where in Chinese roads, railways and pipelines investment. When OBOR project was on the agenda, relations and investments were reorganized in 2015. Infrastructure and financial investments in Pakistan are estimated at approximately 62 billion dollars until 2030 (Mercator Institute For China Studies, 2019). In addition, Pakistan is seen as a strategic region for China due to its border with Afghanistan where is a conflict region and close to the Xinjiang Uyghur Autonomous Region. The investments are expected to make the region more stable in addition to the aim of self-protection of China,

Kazakhstan has also been observed frequently in the analysis. Kazakhstan announced its support for the OBOR project in 2014 and even accepted it as part of its national development vision for 2050. Kazakhstan is seen as the only country in the region which has a multilateral strategic partnership with China. The country is both a supplier of energy and mineral resources and has a position that connects China to Europe. However, its partnership with Russia also creates an advantage for the project (Laruelle, 2018)

As mentioned above, China-Pakistan and Central-West Asia economic corridors are prominent because of the strategic role of Pakistan and Kazakhstan. 
The study can be further expanded by comparing the newspaper contents published in other countries included in OBOR over these categories.

\section{References}

Afzaal, M., Hu, K., Ilyas Chishti, M. \& Khan, Z. (2019). Examining Pakistani News Media Discourses About China-Pakistan Economic Corridor: A Corpus-Based Critical Discourse Analysis. Cogent Social Sciences, vol.5, no.1.

Arifon, O., Huang, Z.A., Yue, Z., \& Yue, A. (2019). Comparing Chinese and European Discourses regarding the "Belt and Road Initiative". Viewed 21 August 2019, < https://halshs.archives-ouvertes.fr/halshs-02308981>

Belt and Road Official Portal (2019). China adds 12.78 billion U.S. dollars of new investment in 56 B\&R countries in first 11 months. Viewed 21 August 2019, <https://eng.yidaiyilu.gov.cn/qwyw/rdxw/113298.htm>

Belt and Road Official Portal (2019). Cooperation Priorities. Viewed 21 August 2019, <https://eng.yidaiyilu.gov.cn/info/iList.jsp?cat_id=10066>

Belt and Road Official Portal (2019). The Belt and Road Initiative Progress, Contributions and Prospects. Viewed 21 August 2019, <https://eng.yidaiyilu.gov.cn/zchj/qwfb/86739.htm>

Blackwill, R. D., \& Harris, J. M (2016). War by Other Means, Harvard University Press.

Creswell, J. W. (2018). Nitel Araştırma Yöntemleri: Beş Yaklaşıma Göre Nitel Araştırma ve Araştırma Deseni, Siyasal Kitabevi.

Durdular, A. (2016). Çin'in Kuşak-Yol Projesi ve Türkiye-Çin İlişkilerine Etkisi. Avrasya Etüdleri. vol.49, no.1, pp. 77-97.

E-Commerce Blog (2019). Did Xi Jinping Conquer Italy or Beautiful Prefer a Lot of Blood Oranges? Viewed 21 August 2019, <https://e-commerce.blog/did-xi-jinping-conqueritaly-or-beautiful-prefer-a-lot-of-blood-oranges/>

Hatef, A., \& Luqiu, L. R. (2018). Where Does Afghanistan Fit in China’s Grand Project? A Content Analysis of Afghan and Chinese News Coverage of the One Belt One Road initiative. International Communication Gazette, vol. 80, no.6, pp. 551-569.

Herrero, A. G., \& Xu, J. (2019). Countries' Perceptions of China's Belt and Road Initiative: A Big Data Analysis. Working Paper, no. 1.

$\mathrm{Hu}$, L. (2019). External Communication Research of the Belt and Road InitiativeComparative analysis of the relevant reports on the Belt and Road Initiative in China daily, CNN and CNBC. In 4th International Conference on Modern Management, Education Technology and Social Science (MMETSS 2019). Atlantis Press, October 2019.

Huang, H. (2018). China's Image in the Belt and Road Initiative: Case Study of Pakistan and India. Master Thesis, Lund University, Sweden.

Laruelle, M. (2018). China's Belt and Road Initiative and Its Impact in Central Asia. Viewed 21 August 2019, <https://eprints.soas.ac.uk/25966/1/dave-silk-road-economic-belteffects-chinas-soft-power-diplomacy-kazakhstan.pdf $>$ 
Lasswell, H. D. (1927). Propaganda Technique in the World War. Ravenio Books.

Mercator Institute for China Studies (2018). The BRI in Pakistan: China's flagship economic corridor. Viewed 21 August 2019, <https://www.merics.org/en/bri-tracker/the-bri-inpakistan>

Okur, M. A. (2017). Bir Kuşak, Bir Yol Projesi’nin Jeopolitiği, Türk Kuşağı ve Uygurlar. Akademik Hassasiyetler, vol. 4, no.8, pp. 45-55.

Pew Research Center (2014). Where News Audiences Fit on the Political Spectrum. Viewed 21 August 2019, <https://www.journalism.org/interactives/mediapolarization/outlet/new-york-times/>

Punch, K. F., \& Akyüz, Z, Bayrak, D \& Arslan B.H. (2016) Sosyal Araştırmalara Giriş: Nicel ve Nitel Yaklaşımlar. Siyasal Kitabevi.

Ravitsky, M. (2018). Jumping onto the Train? How Russian Media Cover China's Belt and Road Initiative. Asian Politics \& Policy, vol. 10, no.3, pp. 564-570.

The New York Times (2013). China Looks West as It Bolsters Regional Ties. Viewed 21 August 2019, <https://www.nytimes.com/2013/09/08/world/asia/china-looks-west-asit-strengthens-regional-ties.html? searchResultPosition=1\%3E $>$

The New York Times (2019). A Forgotten Italian Port Could Become a Chinese Gateway to Europe. Viewed 21 August 2019, <https://www.nytimes.com/2019/03/18/world/europe/italy-trieste-china-beltroad.html>

Xiao, Y., Li, Y., \& Hu, J. (2019). Construction of the Belt and Road Initiative in Chinese and American media: A Critical Discourse Analysis Based on Self-Built Corpora. International Journal of English Linguistics, vol. 9, no. 3, pp. 68-77.

Xin, J., \& Matheson, D. (2018). One Belt, Competing Metaphors: The Struggle over Strategic Narrative in English-language News Media. International Journal of Communication, vol. 12, no. 21 .

Zhang, L., \& Wu, D. (2017). Media Representations of China: A Comparison of China Daily and Financial Times in Reporting on The Belt and Road İnitiative. Critical Arts, vol. 31, no.6, pp. 29-43. 